\title{
Preparation and Analytical Study of Rasa Marit Tamra Bhasma
}

\author{
Research Article
}

\section{Pallavi Prabhakar Jamnekar ${ }^{{ }^{*}}$ \\ 1. Lecturer, Department of Rasashastra and Bhaishjya Kalpana, Bhau Saheb Mulak Ayurvedic Mahavidyalaya, Nagpur}

\begin{abstract}
Tamra Bhasma (TB) is an Ayurvedic medicine, prepared from Copper. It is used in Ayurvedic treatment for various diseases. Though several methods of preparation of Tamra Bhasma are found in Rasashastra classics, several difficulties occur during the preparation of a good-quality Bhasma. Aims and Objectives: To study the process of Tamra Maran by using Rasa Bhasma(kajjali) as intermediray media. To analyze the constituents of Tamra Bhasma. Materials and Methods: Pharmaceutical study- TB was prepared as per the classical guidelines. Analytical study- TB was subjected to various analytical tests like X-ray Diffraction. Results: Copper \% was approximately $64 \%$ in Rasa maarit Tamra bhasma. Copper was present in sulphide form. Conclusion: Rasa bhasma (kajjali) is good media for maran of Tamra.
\end{abstract}

Keywords: Maran, Tamra, Rasa Bhasma, Tamra Bhasma, X-ray diffraction.

\section{Introduction:}

Science is a gradual evolution. It is not a sudden invention and Ayurveda as a science, is not an exception for it. The imperishable fundamentals of Ayurveda, which were laid down by the great acharyas of the olden days are still applicable because of their scientific eternal background. Such fundamentals must be subjected to scientific research not only to prove it's certainty but also to add something new to the existing knowledge.

Rasa kalpa have shown a miraculous effect even there, where the other medicines fail to provide remedy. Depending upon the various types of preparation, Dhatu Bhasma have been proved to be one among the most important and foremost type.

Tamra Bhasma (TB) is an Ayurvedic medicine, prepared from Copper. It is used in Ayurvedic treatment for various diseases. Though several methods of preparation of Tamra Bhasma are found in Rasashastra classics, several difficulties occur during the preparation of a good-quality Bhasma. In this study, TB was prepared by using Rasa Bhasma[1](kajjali) as an intermediary media and analyzed to develop the standard manufacturing procedure. After maran the prepared Tamra Bhasma was subjected to various analytical tests like X-ray diffraction

In this commercial world it is necessary to check the superiority/ inferiority of the bhasma. Accordingly a practical chemical knowledge is required to overcome this lacuna. Therefore a chemical analysis of Rasa Marit Tamra Bhasma is ultimately proposed here.

*Corresponding Author:
Pallavi Prabhakar Jamnekar
Lecturer,
Department of Rasashastra and Bhaishjya Kalpana,
Bhau Saheb Mulak Ayurvedic Mahavidyalaya,
Nagpur
E-mail: pallavi_jamnekar@rediffmail.com

\section{Aims and Objectives:}

To study the process of Tamra Maran by using Rasa Bhasma (kajjali) as intermediary media.

To analyze the constituents of Tamra Bhasma prepared by using Rasa Bhasma as intermediary media.

\section{Material and Methods:}

The experiment was worked out as follows:

\section{Pharmaceutical Study:}

1. Collection of Raw materials

2. Preparation of Kanji

3. Preparation of Kulattha Kwatha

4. Shodhan - Parad, Gandhak, Tamra(samanya and vishesh)

5. Kajjali Preparation

6. Maran

\section{Collection of Raw materials}

All the ingredients were collected from the local market.

\section{Preparation of Kanji [2]:}

Reference

Type of Procedure

Sharangdhar Samhita Madhyam Khanda 10/12

Purpose Fermentation

Samanya Shodhan of Tamra

\section{Preparation of Kulattha Kwatha [3]:}

Reference

Type of Procedure

Purpose
Sharangadhara

Kwatha (boiling)

Samanya shodhan of Madhyama Khanda 2/1 
4) Shodhan of Drugs:

\begin{tabular}{|c|c|c|c|c|}
\hline Sr. no & Parad shodhan[4] & Gandhak shodhan[5] & $\begin{array}{l}\text { Samanya shodhan } \\
\text { of Tamra [6 }\end{array}$ & $\begin{array}{l}\text { Vishesh shodhan of } \\
\text { Tamra[7] }\end{array}$ \\
\hline 1.Reference & R.T. $5 / 31$ & R.T. $8 / 7-11$ & R.R.S 5/13 & R.R.S 5/51 \\
\hline $\begin{array}{l}\text { 2.Type of } \\
\text { procedure }\end{array}$ & Mardan & Dhalan & $\begin{array}{l}\text { Nirvapa } \\
\text { (heating and } \\
\text { quenching) }\end{array}$ & $\begin{array}{l}\text { Nirvapa (heating and } \\
\text { quenching) }\end{array}$ \\
\hline 3.Purpose & $\begin{array}{l}\text { For removing the } \\
\text { impurities }\end{array}$ & $\begin{array}{l}\text { For removing the } \\
\text { impurities }\end{array}$ & $\begin{array}{l}\text { For removing the } \\
\text { impurities }\end{array}$ & $\begin{array}{l}\text { Preparation of } \\
\text { Tamra for Marana }\end{array}$ \\
\hline 4.Ingredients & $\begin{array}{l}\text { Ashuddha parad- } 750 \\
\text { gm } \\
\text { Kumari Swaras- } 750 \\
\text { gm } \\
\begin{array}{l}\text { Chitraka moola- } \\
\text { gm }\end{array} \\
\begin{array}{l}\text { Raktasarshapa- } \\
\text { gm }\end{array} \\
\text { Brihati } \quad 750 \\
\text { Triphala- } 750 \mathrm{gm} \\
\text { Water for decoction }\end{array}$ & $\begin{array}{l}\text { Ashuddha Gandhak- } \\
1000 \text { gm } \\
\text { Gogrit-250 gm } \\
\text { Godugdha-q.s. }\end{array}$ & $\begin{array}{l}\text { Raw Tamra }-300 \\
\text { gm } \\
\text { Media } \\
\text { Til tail } \\
\text { Takra } \\
\text { Gomutra } \\
\text { Kanji } \\
\text { Kulatha kwatha q.s. }\end{array}$ & $\begin{array}{l}\text { Samanya shodhit } \\
\text { Tamra- } 275 \mathrm{gm} \\
\text { Saindhav - } 150 \mathrm{gm} \\
\text { Nimbu swarasa-q.s. }\end{array}$ \\
\hline
\end{tabular}

\section{5] Preparation of Kajjali [8]:}

\begin{tabular}{|l|l|}
\hline Reference & Rasa Tarangini 6/107 \\
\hline Type of Procedure & Mardan \\
\hline Purpose & for Maran of Tamra \\
\hline
\end{tabular}

6]Maran of Tamra [9]:

\begin{tabular}{|l|l|}
\hline Sr. no & Rasa Marit Tamra Bhasma \\
\hline Reference & R.R.S5/53 \\
\hline Type of procedure & Putapaka ( incineration ) \\
\hline Drug for incineration & Kajjali \\
\hline Ingredients & Shudha tamra $\quad-200$ gms \\
& Kajjali $\quad$ gms \\
& Bhavana dravya for marana - jambira nimbu swarasa \\
\hline Groups & RMTB1 \\
& RMTB2 \\
& RMTB3 \\
\hline
\end{tabular}

\section{B] Analytical Study:}

Ayurvedic parameters [10, 11]:

\begin{tabular}{|l|l|l|}
\hline 1. & Varitar & Floats on surface of water \\
\hline 2. & Rekhapurna & Fills the spaces in between finger lines \\
\hline 3. & Nischandra & Without metallic lustre \\
\hline 4. & Avami & Doesnot cause nausea \\
\hline 5. & Nirdhum & Burns without fumes \\
\hline 6. & Unnam & Rice grains floats on bhasma which is floating on water surface \\
\hline 7. & Sookshma & Very fine \\
\hline 8. & Shlakshna & Smooth \\
\hline 9. & Mridu & Soft \\
\hline 10. & Laghu & Light in weight \\
\hline 11. & Amla pariksha & Curd test \\
\hline
\end{tabular}


Physicochemical Study [12]:

1) Description

2) Identification/Detection of elements

3) Successive Solubility in $\mathrm{CS}_{2}, \mathrm{H}_{2} \mathrm{O}, \mathrm{HCl}$, Dilute $\mathrm{HNO}_{3}$, Aquaregia

4) $\mathrm{pH}$ in $1 \%$ and $10 \% \mathrm{sol}$

5) Conductivity in $1 \%$ and $10 \% \mathrm{sol}$

6) Loss on drying at $105^{\circ} \mathrm{C}$

7) Loss on Ignition

8) Elemental Assay for $\mathrm{S}_{\mathrm{SO}}, \mathrm{Cu}, \mathrm{Hg}$

9) $X R D$

\section{Description:}

\begin{tabular}{|l|l|l|l|l|l|}
\hline $\begin{array}{l}\text { Sr. } \\
\text { No. }\end{array}$ & $\begin{array}{l}\text { Sam- } \\
\text { ples }\end{array}$ & Colour & Odour & Taste & Texture \\
\hline 1 & $\begin{array}{l}\text { RMT } \\
\text { B1 }\end{array}$ & $\begin{array}{l}\text { Bluish } \\
\text { black }\end{array}$ & $\begin{array}{l}\text { Odour- } \\
\text { less }\end{array}$ & $\begin{array}{l}\text { Taste- } \\
\text { less }\end{array}$ & Smooth \\
\hline 2 & $\begin{array}{l}\text { RMT } \\
\text { B2 }\end{array}$ & $\begin{array}{l}\text { Bluish } \\
\text { black }\end{array}$ & $\begin{array}{l}\text { Odour- } \\
\text { less }\end{array}$ & $\begin{array}{l}\text { Taste- } \\
\text { less }\end{array}$ & Smooth \\
\hline 3 & $\begin{array}{l}\text { RMT } \\
\text { B3 }\end{array}$ & $\begin{array}{l}\text { Bluish } \\
\text { black }\end{array}$ & $\begin{array}{l}\text { Odour- } \\
\text { less }\end{array}$ & $\begin{array}{l}\text { Taste- } \\
\text { less }\end{array}$ & Smooth \\
\hline \multicolumn{6}{|l|}{} \\
\hline
\end{tabular}

\section{Identification / Detection of Elements}

\section{a) Test for Sulphate:}

About 0.5 gm of sample was taken into test tube and shake well. Then it was centrifuged and upper solution was treated with Barium chloride solution. White precipitate was obtained in all the three samples confirming the presence of sulphate.

b) Test for Sulphide:

About $0.5 \mathrm{gm}$ of sample was taken in the test tube and was treated with dil $\mathrm{HCl}$ and little zinc dust. Evolution of the gas which turns lead acetate paper black confirms the presence of sulphide.

c) Mercury:

Filtrate obtained after treatment of the sample with Bromine and Nitric acid was treated with Charcoal. Filtered portion of the filtrate was treated with little aqueous Ammonia. Very little quantity of granular precipitate appeared which showed the presence of mercury in minor quantity.

\section{Successive Solubility Determination:}

\section{a) Solubility in $\mathbf{C S}_{2}$ :}

Accurately weighed $500 \mathrm{mg}$ of sample was taken in tarred sintered glass crucible. The crucible was kept in a $100 \mathrm{ml}$ beaker. Ice was taken in $500 \mathrm{ml}$ beaker and $100 \mathrm{ml}$ beaker containing sintered glass crucible was kept in it. 4 to $5 \mathrm{ml}$ of $\mathrm{CS}_{2}$ was poured in the sintered glass crucible and covered with watch glass. Then it was shaken gently for few minutes and then sucked by filtration pump. It was dried in air and finally in oven at $105^{\circ} \mathrm{C}$ and weighed. The process was repeated to constant weight.

\section{b) Solubility in $\mathrm{H}_{2} \mathrm{O}$ :}

After above operation the crucible was kept again in $100 \mathrm{ml}$ beaker and $20 \mathrm{ml}$ of water was added in the crucible and $10 \mathrm{ml}$ outside the crucible in the beaker. Then it was boiled for 10 minutes and sucked by filtration pump. Finally it was dried at $105^{\circ} \mathrm{C}$ and weighed. The process was repeated till constant weight.

\section{c) Solubility in dil. $\mathrm{HCl}$ :}

After determination of solubility in water the crucible was kept in a $100 \mathrm{ml}$ beaker and $10 \mathrm{ml}$ of dil $\mathrm{HCl}$ was added in the crucible and $10 \mathrm{ml}$ of water was added to the beaker. Then it was boiled for 10 minutes and sucked by filtration pump. Then dried in oven at $105^{\circ} \mathrm{C}$ and weighed. The process repeated up to constant weight.

d) Solubility in dil. Nitric acid:

After above operation the crucible was kept in $100 \mathrm{ml}$ beaker and $10 \mathrm{ml}$ of dil Nitric acid was added in the crucible and $10 \mathrm{ml}$. of water was added to the beaker. Then it was boiled for 10 minutes and sucked by filtration pump. Then dried in oven at $105^{\circ} \mathrm{C}$ and weighed. The process was repeated up to constant weight.

e) Solubility in Aquaregia:

After determination of solubility in dil Nitric acid the crucible was kept in $100 \mathrm{ml}$ beaker and 5 $\mathrm{ml}$ of Aquaregia was added in the crucible and $10 \mathrm{ml}$. of water was added to the beaker. Then it was boiled for 10 minutes and sucked by filtration pump. Then dried in oven at $105^{\circ} \mathrm{C}$ and weighed. The process was repeated up to constant weight.

\section{4. $\mathrm{pH}(1 \%, 10 \%$ filtered solution $)$}

$0.5 \mathrm{gm}$ and $5 \mathrm{gm}$ of the samples were shaken gently in $40 \mathrm{ml}$ of water for about $1 / 2$ hour, and then filtered. Thus filtrate of $1 \%$ and $10 \%$ suspension was obtained. $\mathrm{pH}$ of filtrate was measured by $\mathrm{pH}$ meter after calibration of the electrode (Toschon - C154 instrument).

\section{Conductivity ( $1 \%, 10 \%$ filtered solution)}

$0.5 \mathrm{gm}$ and $5 \mathrm{gm}$ of the samples were shaken gently in $40 \mathrm{ml}$ of water for about $1 / 2$ hour, and then filtered. Thus filtrate of $1 \%$ and $10 \%$ suspension was obtained. Conductivity of filtrate was measured by standardized electrode of conductivity meter (Systronic Conductivity Bridge 305).

\section{Loss on Drying at $105^{\circ} \mathrm{C}$}

About $1 \mathrm{gm}$ of sample was weighed in LOD crucible and dried at $105^{\circ} \mathrm{C}$ and thereafter cooled in desiccators. Weighing, drying and cooling were repeated to constant weight. Percentage of Loss on drying was calculated.

\section{Loss on Ignition:}

About $1 \mathrm{gm}$ of sample was weighed in tarred silica crucible and heated at temperature not exceeding $450^{\circ} \mathrm{C}$, cooled it in desiccators and weighed. Heating and cooling was repeated to constant weight. Percentage of Loss on Ignition with reference to the air dried drug was calculated.

\section{Elemental Assay:}

\section{A) Estimation of Sulphur:}

Accurately weighed about $500 \mathrm{mg}$ of Bhasma was treated with $3 \mathrm{ml}$ mixture of Bromine in carbon tetra chloride $(2: 3)$. After $5 \mathrm{~min}$. $5 \mathrm{ml}$ of Nitric acid was added to it. Beaker covered with watch glass was allowed to stand for $15-20 \mathrm{~min}$. The covered 
beaker was then heated to $100^{\circ} \mathrm{C}$ till cessation of the action, then the cover was slightly displaced and it was heated to dryness. $5 \mathrm{ml}$ of conc. $5 \mathrm{ml} \mathrm{HCl}$ was added and heated to dryness in water bath. Then again $5 \mathrm{ml}$ $\mathrm{HCl}$ was added and $40 \mathrm{ml}$ warm water was added to it. It was again heated in water bath cooled for $5 \mathrm{~min}$ then it was filtered through cotton, rinsing the cover. Supernatant was separated and residue was washed repeatedly and was pooled together with the initial supernatant. Charcoal was added to it and warmed slightly with stopper at the mouth of flask. It was cooled. Then it was filtered and volume was made 100 $\mathrm{ml}$ with washings. $50 \mathrm{ml}$ of the clear Blue solution was treated with $5 \%$ Barium Chloride and $\mathrm{HCl}$ in excess. It was stirred well. The solution was allowed to stand and ppt obtain was filtered through Whatman number 42 paper and was washed thoroughly to remove Barium chloride. Then filter paper with residue was dried and ignited at 700 to $800^{\circ} \mathrm{C}$ in tarred Silica crucible to constant weight.

\section{B) Estimation of Copper:}

$0.4 \mathrm{ml}$ of the solution was taken from the solution left behind in sulphur estimation. $4.1 \mathrm{ml}$ of water was added to it followed by addition of $0.5 \mathrm{ml}$ of Ammonia solution (1:1) and its O.D. was measured as 660nm.

$1 \%$ Copper sulphate solution was used as standard the aliquot of $0.3,0.4,0.5,0.6,0.7 \mathrm{ml}$ with water to make the volume $4 \mathrm{ml}$ and followed by addition of $0.5 \mathrm{ml}$ of Ammonia solution (1:1) using water as blank.

Observation and Results:

Table 1: Puta wise observation of Rasa Marit Tamra Bhasma

\begin{tabular}{|c|c|c|c|c|c|c|c|c|c|}
\hline $\begin{array}{l}\text { No. } \\
\text { of } \\
\text { Pu- } \\
\text { ta }\end{array}$ & $\begin{array}{l}\text { Material } \\
\text { added to } \\
\text { Sh. tamra } \\
\text { (kajjali) } \\
\text { gandhak) }\end{array}$ & Colour & $\begin{array}{l}\text { Con- } \\
\text { sistancy }\end{array}$ & $\begin{array}{l}\text { Chan- } \\
\text { drika }\end{array}$ & $\begin{array}{l}\text { Rek- } \\
\text { hapurna } \\
\text { tva }\end{array}$ & Varitar & $\begin{array}{l}\text { Amla } \\
\text { Parik- } \\
\text { sha }\end{array}$ & $\begin{array}{l}\text { Wt. } \\
\text { ob- } \\
\text { tained } \\
\text { (g) }\end{array}$ & $\begin{array}{l}\text { No. of } \\
\text { cow } \\
\text { dung } \\
\text { cakes }\end{array}$ \\
\hline 1 & $\begin{array}{l}\text { Equal } \\
\text { kajjali }\end{array}$ & $\begin{array}{l}\text { Reddish } \\
\text { black }\end{array}$ & Hard & ++++ & ++ & - & - & 249 & 56 \\
\hline 2 & $\begin{array}{l}\text { Equal } \\
\text { kajjali }\end{array}$ & $\begin{array}{l}\text { Reddish } \\
\text { black }\end{array}$ & Hard & ++++ & ++ & - & - & 235 & 50 \\
\hline 3 & $\begin{array}{l}\text { Equal } \\
\text { kajjali }\end{array}$ & Black & $\begin{array}{l}\text { Brittle \& } \\
\text { smooth }\end{array}$ & +++ & ++ & + & ++ & 220 & 43 \\
\hline 4 & $1 / 2$ kajjali & $\begin{array}{l}\text { Bluish } \\
\text { black }\end{array}$ & $\begin{array}{l}\text { Brittle \& } \\
\text { smooth }\end{array}$ & ++ & ++++ & + & ++ & 205 & 30 \\
\hline 5 & $\begin{array}{lr}1 / 2 & \text { kajjali } \\
+ & 1 / 2 \\
\text { gandhak }\end{array}$ & Black & $\begin{array}{l}\text { More brit- } \\
\text { tle }\end{array}$ & ++ & +++ & ++ & ++ & 199.8 & 23 \\
\hline 6 & $\begin{array}{lr}1 / 4 & \text { kajjali } \\
+ & 1 / 4 \\
\text { gandhak }\end{array}$ & $\begin{array}{l}\text { Bluish } \\
\text { black }\end{array}$ & $\begin{array}{l}\text { More brit- } \\
\text { tle }\end{array}$ & ++ & +++ & +++ & + & 206.4 & 15 \\
\hline 7 & $\begin{array}{lr}1 / 4 & \text { kajjali } \\
+ & 1 / 4 \\
\text { gandhak }\end{array}$ & $\begin{array}{l}\text { Bluish } \\
\text { Black }\end{array}$ & $\begin{array}{l}\text { More brit- } \\
\text { tle \& } \\
\text { smooth }\end{array}$ & + & +++++ & ++++ & - & 217 & 8 \\
\hline
\end{tabular}

C) Estimation of Sulphate:

About $5 \mathrm{gm}$ each sample was taken. $25 \mathrm{ml}$ water and $0.5 \mathrm{ml} \mathrm{HCl}$ was added to it. It was allowed to stand for 5- 10 mins with intermittent shaking. Then it was filtered and the residue was washed several times so that the volume goes to nearby $150-200 \mathrm{ml}$. Then add conc. $\mathrm{HCl} 1 \mathrm{ml}$ and 200- $300 \mathrm{mg}$ Alumimium powder Shake well and then fioter it with washing 45 times. Add $2 \mathrm{ml}$ conc. $\mathrm{HCl}$ and $5 \%$ warm Barium chloride sol to the filterate in excess . it was allowed to settle down and clear supernatant was obtained and ppt was obtained. It was then filtered through Whatmaan no. 42 paper and washed thoroughly to remove $\mathrm{BaCl} 2$. The paper was dried and ignited upto constant weight.

\section{D) Estimation of Mercury:}

A Trial of estimation of mercury in Rasa maarit Tamra Bhasma by $\mathrm{H}_{2} \mathrm{~S}$ gas did not leave behind any black ppt. After its treatment with hot dil Nitric acid shows that mercury is not present in sufficient quantity to be estimated in general.

\section{XRD (X-ray diffraction or crystallography):}

X-ray diffraction patterns were obtained using Shimadzu XRD 6000 diffractometer with Cu-KX a target with $40 \mathrm{KV}$ voltage and $30 \mathrm{MA}$ current. The Xray diffraction of sample was matched against the standard reference spectra library. 


\begin{tabular}{|c|c|c|c|c|c|c|c|c|c|}
\hline $\begin{array}{l}\text { No. } \\
\text { of } \\
\text { Pu- } \\
\text { ta }\end{array}$ & $\begin{array}{l}\text { Material } \\
\text { added to } \\
\text { Sh. tamra } \\
\text { (kajjali) } \\
\text { gandhak) }\end{array}$ & Colour & $\begin{array}{l}\text { Con- } \\
\text { sistancy }\end{array}$ & $\begin{array}{l}\text { Chan- } \\
\text { drika }\end{array}$ & $\begin{array}{l}\text { Rek- } \\
\text { hapurna } \\
\text { tva }\end{array}$ & Varitar & $\begin{array}{l}\text { Amla } \\
\text { Pariksha }\end{array}$ & $\begin{array}{l}\text { Wt. } \\
\text { ob- } \\
\text { tained } \\
\text { (g) }\end{array}$ & $\begin{array}{l}\text { No. } \\
\text { of } \\
\text { cow } \\
\text { dung } \\
\text { cake } \\
\text { s }\end{array}$ \\
\hline 8 & $\begin{array}{l}\text { 1/4 kajjali + } \\
1 / 4 \\
\text { gandhak }\end{array}$ & $\begin{array}{l}\text { Bluish } \\
\text { Black }\end{array}$ & $\begin{array}{l}\text { More brit- } \\
\text { tle }\end{array}$ & + & ++++ & +++ & - & 222 & 10 \\
\hline 9 & $\begin{array}{l}/ 4 \\
\text { gandhak }\end{array}$ & $\begin{array}{l}\text { Bluish } \\
\text { black }\end{array}$ & $\begin{array}{l}\text { More brit- } \\
\text { tle \& } \\
\text { smooth }\end{array}$ & - & ++++ & ++++ & - & 232 & 4 \\
\hline 10 & $\begin{array}{l}1 / 4 \\
\text { gandhak }\end{array}$ & $\begin{array}{l}\text { Bluish } \\
\text { black }\end{array}$ & $\begin{array}{l}\text { More brit- } \\
\text { tle \& } \\
\text { smooth }\end{array}$ & - & ++++ & ++++ & - & 217 & 4 \\
\hline
\end{tabular}

Table 2: Puta wise observation of Rasa Marit Tamra Bhasm 2

\begin{tabular}{|c|c|c|c|c|c|c|c|c|c|}
\hline $\begin{array}{l}\text { Pu- } \\
\text { ta } \\
\text { no. }\end{array}$ & $\begin{array}{l}\text { Material } \\
\text { added to } \\
\text { Sh. tamra } \\
\text { (kajjali/ } \\
\text { gandhak }\end{array}$ & Colour & $\begin{array}{l}\text { Con- } \\
\text { sistency }\end{array}$ & $\begin{array}{l}\text { Chan } \\
\text { drika }\end{array}$ & $\begin{array}{l}\text { Rek- } \\
\text { hapurn } \\
\text { atva }\end{array}$ & Varitar & $\begin{array}{l}\text { Amla } \\
\text { Pariksha }\end{array}$ & $\begin{array}{l}\text { Wt. } \\
\text { ob- } \\
\text { tained } \\
\text { (g) }\end{array}$ & $\begin{array}{l}\text { No. of } \\
\text { cow } \\
\text { dung } \\
\text { cakes }\end{array}$ \\
\hline 1 & $\begin{array}{l}\text { Equal } \\
\text { kajjali }\end{array}$ & $\begin{array}{l}\text { Reddish } \\
\text { black }\end{array}$ & Hard & ++++ & ++ & - & - & 238 & 56 \\
\hline 2 & $\begin{array}{l}\text { Equal } \\
\text { kajjali }\end{array}$ & $\begin{array}{l}\text { Reddish } \\
\text { black }\end{array}$ & Hard & ++++ & ++ & - & - & 224 & 50 \\
\hline 3 & $\begin{array}{l}\text { Equal } \\
\text { kajjali }\end{array}$ & Black & $\begin{array}{l}\text { Brittle \& } \\
\text { smooth }\end{array}$ & $\overline{+++}$ & ++ & + & ++ & 208 & 43 \\
\hline 4 & $1 / 2$ kajjali & $\begin{array}{l}\text { Bluish } \\
\text { black }\end{array}$ & $\begin{array}{l}\text { Brittle \& } \\
\text { smooth }\end{array}$ & $\overline{++}$ & +++ & + & ++ & 214 & 30 \\
\hline 5 & $\begin{array}{l}\text { 1/2 kajjali }+ \\
1 / 2 \text { gandhak }\end{array}$ & $\begin{array}{l}\text { Bluish } \\
\text { Black } \\
\text { with yel- } \\
\text { lowish } \\
\text { tinge }\end{array}$ & $\begin{array}{l}\text { More brit- } \\
\text { tle }\end{array}$ & ++ & +++ & ++ & ++ & 220 & 23 \\
\hline 6 & $\begin{array}{l}\text { 1/4 kajjali + } \\
1 / 4 \text { gandhak }\end{array}$ & $\begin{array}{l}\text { Bluish } \\
\text { black }\end{array}$ & $\begin{array}{l}\text { More brit- } \\
\text { tle }\end{array}$ & ++ & +++ & +++ & + & 229.4 & 15 \\
\hline 7 & $\begin{array}{l}\text { 1/4 kajjali }+ \\
1 / 4 \text { gandhak }\end{array}$ & $\begin{array}{l}\text { Bluish } \\
\text { Black }\end{array}$ & $\begin{array}{l}\text { More brit- } \\
\text { tle \& } \\
\text { smooth }\end{array}$ & + & ++++ & ++++ & - & 237 & 8 \\
\hline 8 & $\begin{array}{l}\text { 1/4 kajjali }+ \\
1 / 4 \text { gandhak }\end{array}$ & $\begin{array}{l}\text { Bluish } \\
\text { Black }\end{array}$ & $\begin{array}{l}\text { More brit- } \\
\text { tle }\end{array}$ & + & $\overline{++++}$ & +++ & - & 251 & 10 \\
\hline$\overline{9}$ & 1/4 gandhak & $\begin{array}{l}\text { Bluish } \\
\text { black }\end{array}$ & $\begin{array}{l}\text { More brit- } \\
\text { tle \& } \\
\text { smooth }\end{array}$ & - & $\overline{++++}$ & ++++ & - & 235 & 4 \\
\hline
\end{tabular}


Table 3: Puta wise observation of Rasa maarit Tamra Bhasm 3

\begin{tabular}{|c|c|c|c|c|c|c|c|c|c|}
\hline $\begin{array}{l}\text { Pu- } \\
\text { ta } \\
\text { no. }\end{array}$ & $\begin{array}{l}\text { Material } \\
\text { added to } \\
\text { Sh. tamra } \\
\text { (kajjali/ } \\
\text { gandhak) }\end{array}$ & Colour & $\begin{array}{l}\text { Con- } \\
\text { sistancy }\end{array}$ & $\begin{array}{l}\text { Chan- } \\
\text { drika }\end{array}$ & $\begin{array}{l}\text { Rek- } \\
\text { hapurna } \\
\text { tva }\end{array}$ & Varitar & $\begin{array}{l}\text { Amla } \\
\text { Pariksha }\end{array}$ & $\begin{array}{l}\text { Wt. } \\
\text { ob- } \\
\text { tained } \\
\text { (g) }\end{array}$ & $\begin{array}{l}\text { No. of } \\
\text { cow } \\
\text { dung } \\
\text { cakes }\end{array}$ \\
\hline 1 & $\begin{array}{l}\text { Equal } \\
\text { kajjali }\end{array}$ & $\begin{array}{l}\text { Red- } \\
\text { dish } \\
\text { black }\end{array}$ & Hard & ++++ & ++ & - & - & 249 & 56 \\
\hline 2 & $\begin{array}{l}\text { Equal } \\
\text { kajjali }\end{array}$ & $\begin{array}{l}\text { Red- } \\
\text { dish } \\
\text { black }\end{array}$ & Hard & ++++ & ++ & - & - & 235 & 50 \\
\hline 3 & $\begin{array}{l}\text { Equal } \\
\text { kajjali }\end{array}$ & Black & $\begin{array}{l}\text { Brittle \& } \\
\text { smooth }\end{array}$ & +++ & ++ & + & ++ & 220 & 43 \\
\hline 4 & $1 / 2$ kajjali & $\begin{array}{l}\text { Bluish } \\
\text { black } \\
\text { with } \\
\text { yellow } \\
\text { tinge } \\
\end{array}$ & $\begin{array}{l}\text { Brittle \& } \\
\text { smooth }\end{array}$ & ++ & +++ & + & ++ & 205 & 30 \\
\hline 5 & $\begin{array}{l}1 / 2 \text { kajjali }+ \\
1 / 2 \text { gandhak }\end{array}$ & Black & $\begin{array}{l}\text { More brit- } \\
\text { tle }\end{array}$ & ++ & $\overline{+++}$ & ++ & ++ & 199.8 & 23 \\
\hline 6 & $\begin{array}{l}\text { 1/4 kajjali } \\
+1 / 4 \\
\text { gandhak }\end{array}$ & $\begin{array}{l}\text { Bluish } \\
\text { black }\end{array}$ & $\begin{array}{l}\text { More brit- } \\
\text { tle }\end{array}$ & ++ & +++ & +++ & + & 206.4 & 15 \\
\hline 7 & $\begin{array}{l}1 / 4 \text { kajjali }+ \\
1 / 4 \text { gandhak }\end{array}$ & $\begin{array}{l}\text { Bluish } \\
\text { Black }\end{array}$ & $\begin{array}{l}\text { More brit- } \\
\text { tle \& } \\
\text { smooth }\end{array}$ & + & ++++ & +++ & - & 217 & 8 \\
\hline 8 & $\begin{array}{l}1 / 4 \text { kajjali }+ \\
1 / 4 \text { gandhak }\end{array}$ & $\begin{array}{l}\text { Bluish } \\
\text { Black }\end{array}$ & $\begin{array}{l}\text { More brit- } \\
\text { tle }\end{array}$ & + & ++++ & +++ & - & 222 & 10 \\
\hline
\end{tabular}

Analytical Study:

Organoleptic Parameters:

Rasa maarit Tamra Bhasma:

\begin{tabular}{|c|c|c|c|}
\hline Parameter & RMTB1 & RMTB2 & RMTB3 \\
\hline A] Shabda & $\begin{array}{l}\text { No metallic sound when } \\
\text { crushed between teeth }\end{array}$ & $\begin{array}{l}\text { No metallic sound when } \\
\text { crushed between teeth }\end{array}$ & $\begin{array}{l}\text { No metallic sound when } \\
\text { crushed between teeth }\end{array}$ \\
\hline B] Sparsha & $\begin{array}{l}\text { No course particles by } \\
\text { touch (Shlakshna) }\end{array}$ & $\begin{array}{l}\text { No course particles by } \\
\text { touch (Shlakshna) }\end{array}$ & $\begin{array}{l}\text { No course particles by } \\
\text { touch (Shlakshna) }\end{array}$ \\
\hline $\begin{array}{l}\text { C] Rupa } \\
\text { 1. Colour } \\
\text { 2. Susnigdham }\end{array}$ & $\begin{array}{l}\text { Bluish Black } \\
\text { Oleated in consistency }\end{array}$ & $\begin{array}{l}\text { Bluish Black } \\
\text { Oleated in consistency }\end{array}$ & $\begin{array}{l}\text { Bluish Black } \\
\text { Oleated in consistency }\end{array}$ \\
\hline 3. Nishchandratvam & No metallic lustre & No metallic lustre & No metallic lustre \\
\hline 4. Rekhapurnatva & $\begin{array}{l}\text { Filled the fine spaces be- } \\
\text { tween finger lines }\end{array}$ & $\begin{array}{l}\text { Filled the fine spaces be- } \\
\text { tween finger lines }\end{array}$ & $\begin{array}{l}\text { Filled the fine spaces be- } \\
\text { tween finger lines }\end{array}$ \\
\hline $\begin{array}{l}\text { 5. Varitar } \\
\text { 6. Unnam }\end{array}$ & $\begin{array}{l}\text { Floats on surface of water } \\
\text { Grains of rice float on the } \\
\text { Bhasma floating on water. }\end{array}$ & $\begin{array}{l}\text { Floats on surface of water } \\
\text { Grains of rice float on the } \\
\text { Bhasma floating on water. }\end{array}$ & $\begin{array}{l}\text { Floats on surface of water } \\
\text { Grains of rice float on the } \\
\text { Bhasma floating on water }\end{array}$ \\
\hline D] Rasa & Tasteless (Niswadu) & Tasteless (Niswadu) & Tasteless (Niswadu) \\
\hline E] Gandha & No Specific & No Specific & No Specific \\
\hline F] Curd Test & Passed after 72 hours & Passed after 72 hours & Passed after 72 hours \\
\hline
\end{tabular}


Physiochemical Study:

Description of Rasa Marit Tamra Bhasma Samples:

\begin{tabular}{|l|l|l|l|l|l|}
\hline Sr.No. & Samples & Colour & Odour & Taste & Texture \\
\hline 1 & RMTB1 & Bluish black & Odourless & Tasteless & Smooth \\
\hline 2 & RMTB2 & Bluish black & Odourless & Tasteless & Smooth \\
\hline 3 & RMTB3 & Bluish black & Odourless & Tasteless & Smooth \\
\hline
\end{tabular}

\section{Results:}

\begin{tabular}{|c|c|c|c|c|}
\hline Sr.no. & Analytical Tests & RMTB1 & RMTB2 & RMTB3 \\
\hline \multirow[t]{6}{*}{1.} & solubility & & & \\
\hline & $C S_{2}$ & $5.4 \% \mathrm{w} / \mathrm{w}$ & $4.00 \% \mathrm{w} / \mathrm{w}$ & $7.00 \% \mathrm{w} / \mathrm{w}$ \\
\hline & $\mathrm{H}_{2} \mathrm{O}$ & $1.54 \% \mathrm{w} / \mathrm{W}$ & $1.40 \% \mathrm{w} / \mathrm{w}$ & $2.00 \% \mathrm{w} / \mathrm{w}$ \\
\hline & $\mathrm{HCl}$ & $3.06 \% \mathrm{w} / \mathrm{w}$ & $4.60 \% \mathrm{w} / \mathrm{w}$ & $6.00 \% \mathrm{w} / \mathrm{w}$ \\
\hline & $\mathrm{HNO}_{3}$ & $85.00 \% \mathrm{w} / \mathrm{w}$ & $80.00 \% \mathrm{w} / \mathrm{w}$ & $79.20 \% \mathrm{w} / \mathrm{w}$ \\
\hline & Aquqregia & $3.80 \% \mathrm{w} / \mathrm{w}$ & $8.00 \% \mathrm{w} / \mathrm{w}$ & $4.80 \% \mathrm{w} / \mathrm{w}$ \\
\hline \multirow[t]{3}{*}{2.} & $p H$ & & & \\
\hline & 1\%solution & $3.81 \% \mathrm{w} / \mathrm{w}$ & $3.61 \% \mathrm{w} / \mathrm{w}$ & $3.72 \% \mathrm{w} / \mathrm{w}$ \\
\hline & 10\%solution & $3.14 \% \mathrm{w} / \mathrm{w}$ & $2.77 \% \mathrm{w} / \mathrm{w}$ & $3.10 \% \mathrm{w} / \mathrm{w}$ \\
\hline \multirow[t]{3}{*}{3.} & Conductivity & & & \\
\hline & 1.1\%solution & $409.6 \times 10^{2} \mu \mathrm{mhos}$ & $608 \times 10^{3} \mu$ mhos & $531.2 \times 10^{2}$ \\
\hline & 2. 10\%solution & $2592 \times 10^{3} \mu \mathrm{mhos}$ & $4288 \times 10^{3} \mu \mathrm{mhos}$ & $3264 \times 10^{3} \mu \mathrm{mhos}$ \\
\hline 4. & Loss on drying & $0.88 \% \mathrm{w} / \mathrm{w}$ & $1.50 \% \mathrm{w} / \mathrm{W}$ & $1.96 \% \mathrm{w} / \mathrm{w}$ \\
\hline 5. & Loss on Ignition & $-2.20 \% \mathrm{w} / \mathrm{w}$ & $-2.70 \% \mathrm{w} / \mathrm{w}$ & $-0.50 \% \mathrm{w} / \mathrm{w}$ \\
\hline \multirow[t]{4}{*}{6.} & Elemental Assay & & & \\
\hline & Estimation of $S$ & $28.51 \% \mathrm{w} / \mathrm{w}$ & $28.70 \% \mathrm{w} / \mathrm{w}$ & $28.43 \% \mathrm{w} / \mathrm{w}$ \\
\hline & Estimation of $\mathrm{Cu}$ & $68.86 \% \mathrm{w} / \mathrm{w}$ & $63.73 \% \mathrm{w} / \mathrm{w}$ & $63.55 \% \mathrm{w} / \mathrm{w}$ \\
\hline & Estimation of $\mathrm{SO}_{4}$ & $0.3626 \% \mathrm{w} / \mathrm{w}$ & $0.2549 \% \mathrm{w} / \mathrm{w}$ & $0.3132 \% \mathrm{w} / \mathrm{w}$ \\
\hline
\end{tabular}

$\mu$ mhos- micro mhos (unit of conductivity)

\section{Qualitative tests:}

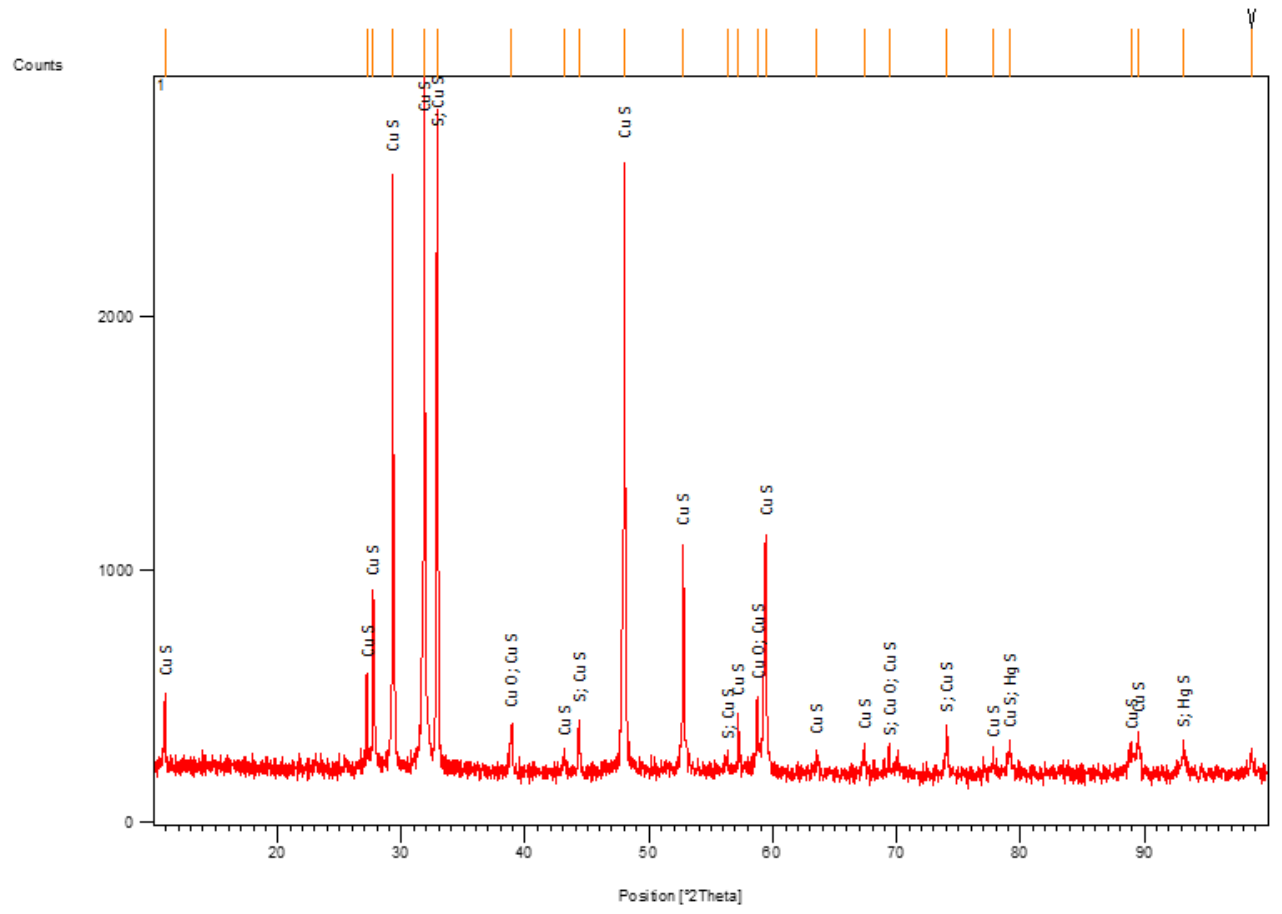




\section{Discussion:}

During pharmaceutical study all the process involved in preparation were manual. Hence slight batch to batch variations were observed. Changes were made in the number of cow dung cakes, amount of kajjali and gandhak to be added as per requirement.

\section{Parad maarit tamra bhasma :}

Maran was done by using kajjali as media. The amount of kajjali was changed as per requirement. Changes were made in the number of cow dung cakes as per requirement. Colour variations were also observed in each puta. Colour difference was also seen in the same sharava due to temperature difference in the sharava samputa. Hence it is necessary to cover the sharavas uniformly with cow dung cakes to avoid such variations.

\section{"Lohanam Maranam Srestham Sarvesham}

\section{Rasa Bhasmana[13]"}

The word Rasa Bhasma has always been in controversy. It is difficult to prepare the Bhasma of $\mathrm{Hg}$ (Rasa). Keeping in mind the sayings of Dr. D. A. Kulkarni, many Rasa preparations are considered as Rasa Bhasmas; such as -Kajjali, Rasa Sindura, Rasakarpura, Hingula, etc.

Here in the present context - Kajjali was taken,and considering this as Rasa bhasmas, the preparation of Tamra Bhasma was done.

\section{Conclusion:}

The following conclusions were made on the basis of observations and results obtained..

- Copper \% was approximately 64\% in Rasa maarit Tamra bhasma.

- Kajjali can be a better media for the preparation of Bhasma.

- Rasa maarit tamra bhasma requires less number of putas.

- Rasa maarit Tamra Bhasma can be prepared in relatively less duration.

\section{Referrences:}

1. Rasratna Sammuchya, Vaghbhatacharya, Vidngyanbodhini Hindi Commentary, Prof. Dattatraya Antant Kulkarni, reprint edition- New Delhi, Meherchand Lachamandas Publication, 2007,
Pg. No.94

2. Sharangdhar Samhita,Acharya Radhakrishna Parashar, Baidyanath Bhavan, $4^{\text {th }}$ Ed., 1994, 362.

3. Sharangdhar Samhita,Acharya Radhakrishna Parashar, Baidyanath Bhavan, $4^{\text {th }}$ Ed., 1994, 186.

4. Rasatarangini, Sadanand Sharma, kashinath Shastri, Motilal Banarasidas, $11^{\text {th }}$ edition,1979, Re edition 1982, 1989, 80.

5. Rasatarangini, Sadanand Sharma, kashinath Shastri, Motilal Banarasidas, $11^{\text {th }}$ edition,1979, Re edition 1982, 1989, 176 .

6. Rasratna Sammuchya, Vaghbhatacharya, Vidngyanbodhini Hindi Commentary, Prof. Dattatraya Antant Kulkarni, reprint edition- New Delhi, Meherchand Lachamandas Publication, 2007,Pg. No. 93.

7. Rasratna Sammuchya, Vaghbhatacharya, Vidngyanbodhini Hindi Commentary, Prof. Dattatraya Antant Kulkarni, reprint edition- New Delhi, Meherchand Lachamandas Publication, 2007, Pg. No. 101.

8. Rasatarangini, Sadanand Sharma, kashinath Shastri, Motilal Banarasidas, $11^{\text {th }}$ edition, 1979, Re edition 1982, 1989, 124.

9. Rasratna Sammuchya, Vaghbhatacharya, Vidngyanbodhini Hindi Commentary, Prof. Dattatraya Antant Kulkarni, reprint edition- New Delhi, Meherchand Lachamandas Publication, 2007, Pg. No. 101.

10. Ayurvediya Ras Shastra, Siddhinandan Mishra, chaukhamba Orientalia., $9^{\text {th }}$ Ed., 1999,99.

11. Honwad, Handbook of Standardization of Ayurvedic Formulations, Chaukhamba Orentalia, $1^{\text {st }}$ edition, 2012.

12. Honwad, Handbook of Standardization of Ayurvedic Formulations, Chaukhamba Orentalia, $1^{\text {st }}$ edition, 2012.

13. Rasratna Sammuchya, Vaghbhatacharya, Vidngyanbodhini Hindi Commentary, Prof. Dattatraya Antant Kulkarni, reprint edition- New Delhi, Meherchand Lachamandas Publication, 2007,Pg. No. 94

\section{PHARMACEUTICAL STUDY}

\section{PARAD SHODHAN :}

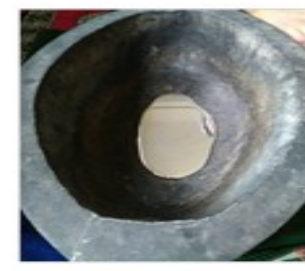

i) ASHUDHA PARAD

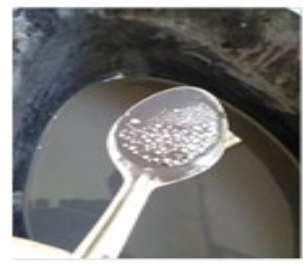

ii) PARAD DURING

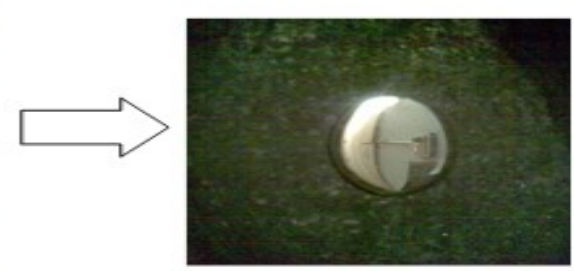

ii) PAR AD AFTER SHODHAN

SHODHAN 


\section{GANDHAK SHODHAN:}

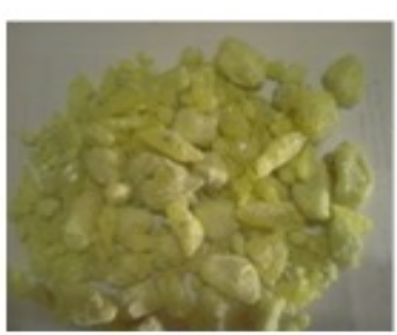

i) ASHUDHA GANDHAK

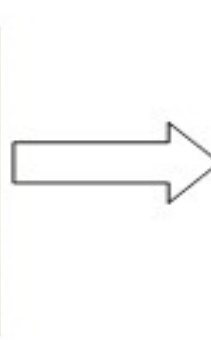

ii)
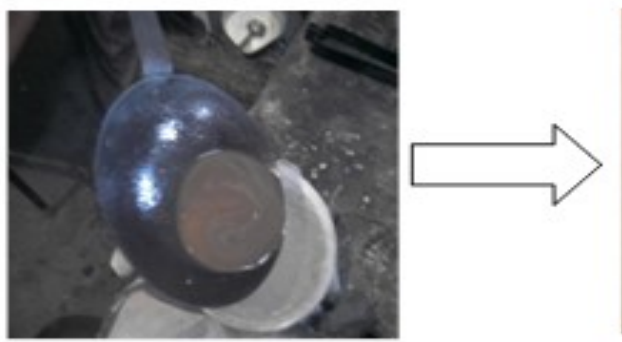

iii) SHUDHA GANDHAK

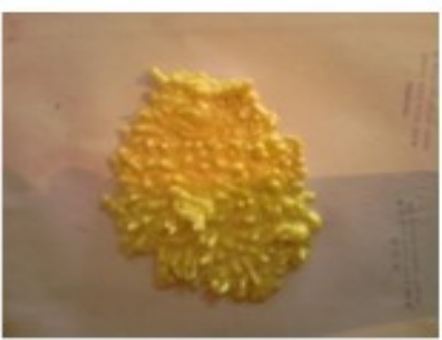

IN GODUGDHA

\section{TAMRA SHODHAN:}

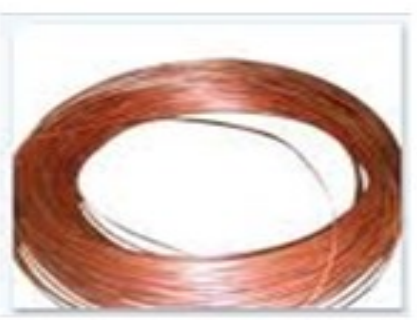

i) ASHUDHA TAMRA

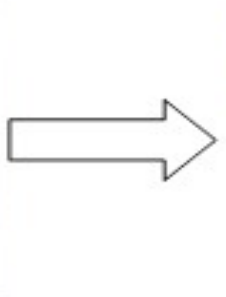

ii) NIR VAPAN OF TAMRA 


\section{ANALYTICAL STUDY}

\section{AYURVEDIC PARAMETERS:}

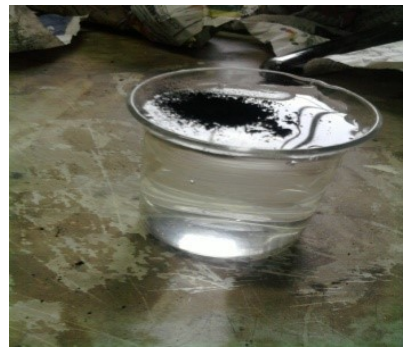

i) VIRITAR

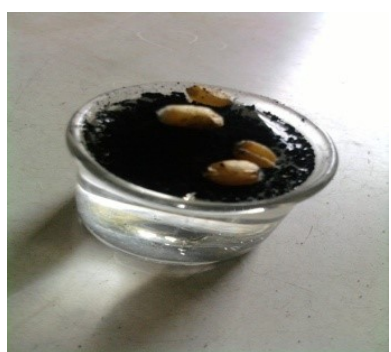

ii) UTTAM

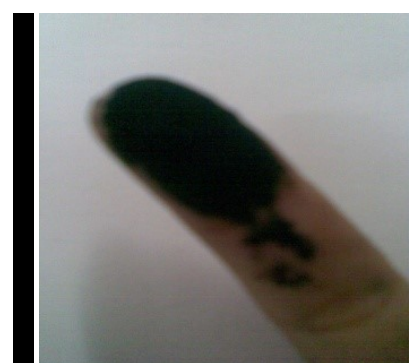

iii) REKHAPURNA

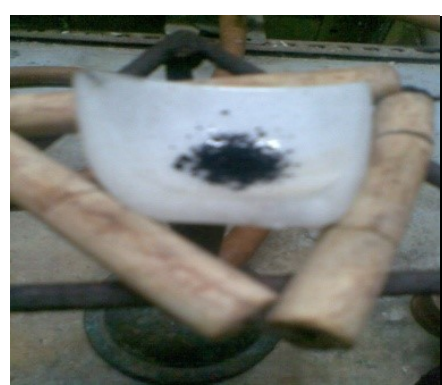

iv)NIRDHUM

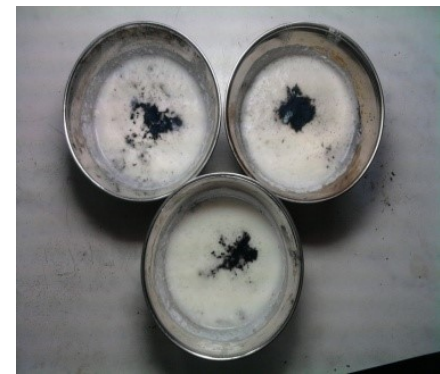

v) CURD TEST

\section{MODERN PARAMETERS:}

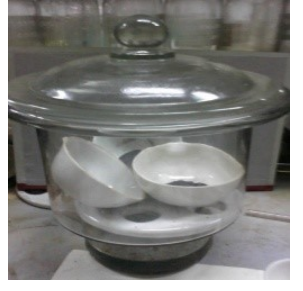

i) L.O.D

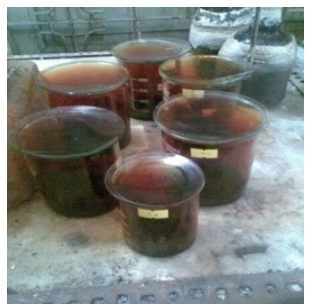

v) ASSAY FOR SULPHUR

ii) L.O.I
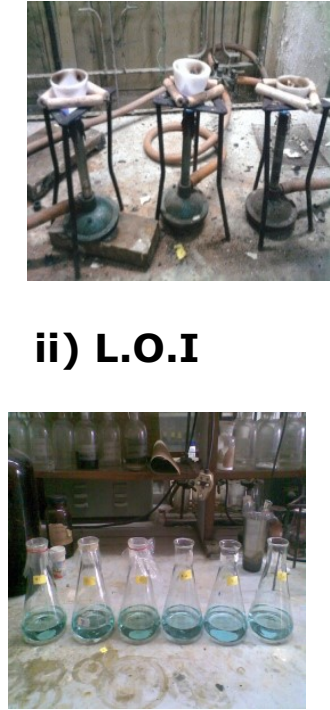

vi) ASSAY FOR Cu

iii) SOLUBILITY

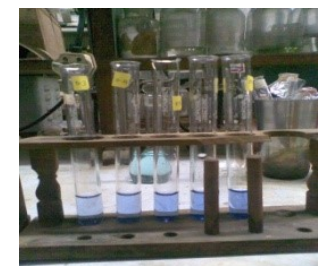

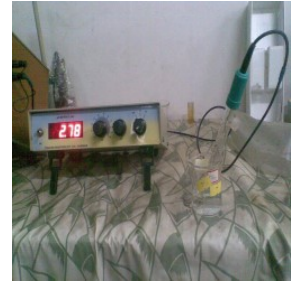

iv) $\mathbf{p H}$

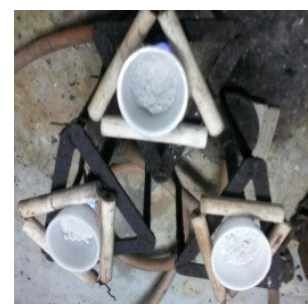

vii)ASSAY FOR $\mathrm{SO}_{4}$ 